\title{
THE EFFECTS OF IRRIGATION REGIMES ON SOIL MOISTURE DYNAMICS, YIELD AND QUALITY OF LUCERNE UNDER SUBSURFACE DRIP IRRIGATION
}

\author{
WANG, Y. D. ${ }^{1}-$ Kou, D. ${ }^{2}-$ MunEeR, M. A. ${ }^{1}-$ FANG, G. J. ${ }^{1}-$ Su, D, R. ${ }^{1 *}$ \\ ${ }^{1}$ College of Grassland Science, Beijing Forestry University, Beijing 100083, China \\ ${ }^{2}$ State Key Laboratory of Vegetation and Environmental Change, Institute of Botany, Chinese \\ Academy of Sciences, Beijing 100093, China \\ ${ }^{*}$ Corresponding author \\ e-mail: suderong@bjfu.edu.cn; phone: +86-10-6233-6284
}

(Received $17^{\text {th }}$ Sep 2019; accepted $21^{\text {st }}$ Jan 2020)

\begin{abstract}
Lucerne (Medicago sativa L.), as a grass legume is mowed many times in the Hexi Corridor, PR of China, which holds a vital position in the crop-pasture and animal husbandry. Cultivating high-quality lucerne under such extreme water shortage conditions is a necessary approach to develop regulated deficit irrigation (RDI). However, applications of Regulated Deficit Drip Irrigation (RDDI) needs to be explored further in order to increase both the yield and quality of lucerne. Therefore, the main objective of this study was to investigate the effect of different regulated deficit irrigation on soil moisture (SM) dynamics, yield and quality of lucerne. A field experiment was designed with four deficit irrigation treatments in the year of 2013 and 2017. The lucerne was harvested three times per year. Our results showed that with deficit drip irrigation increasing, the yield was decreased for lucerne crop, crude protein (CP), and relative feed value (RFV), while, the content of CP and RFV was increased. SM was directly proportional to the amount of irrigation volume except high water deficit (HWD). Deep SM showed that annual lucerne SM was greater in HWD than in low water deficit (LWD). The biennial lucerne SM was greater in HWD than in each treatment in most cases. Considering the influence factors of yield, qualities and water use efficiency (WUEs (Including WUE, WUE CP and WUE $\mathrm{RFV}$ )), it is more appropriate that annual lucerne should not be treated with deficit irrigation. In the following year, the LWD reduced the forage yield, but more or less increased the yield of $\mathrm{CP}\left(\mathrm{CP}_{\text {yield }}\right)$ and $\mathrm{RFV}$ ( $\left.\mathrm{RFV}_{\text {yield }}\right)$ to compensate the loss of forage yield.
\end{abstract}

Keywords: Medicago sativa L., regulated deficit irrigation, crude protein, relative feed value, water use efficiency

\section{Introduction}

Lucerne (Medicago sativa L), is known as "Queen of Forages" because of its high yield, extraordinary protein quality, and best nutritive value as a forage, plays an important role in crop-pasture and animal husbandry systems all over the world (Bouton, 2012). In the United States, lucerne is the fourth largest crop after maize, wheat and soybean, with an area of over 10 million hectares, accounting for about one third of the world's total cultivated area (Hanson, 2007). In contrast, lucerne planting industry in China is lagging behind and accounts for only $4.5 \%$ of the world's total planting area (industry compare to plants area, shoud be considered further). In addition, lucerne production in China is low and of poor quality. Because the crude protein content of lucerne products varies 16\%-20\%, which falls between level 2 and 3, (the quality standards issued by the state), and some products have even lower than $16 \%$ (Kou et al., 2014). As a resultant, China has become the largest importer of lucerne in the world (www.mofcom.gov.cn/). So, there is an urgent need to increase the large-scale cultivation of lucerne to develop high-yielding and high-quality lucerne industry in China. 
Hexi Corridor is located in arid and semi-arid area of Northwest China, where rainfall is scarce and atmospheric evaporative demand is very large, as a resultant limited available water resources have posed a serious threat to the sustainable and stable development of local agriculture and animal husbandry (Kou et al., 2014; Xiao et al., 2015). Therefore, the development of ecological water conservation must be required to improve the water use efficiency of crops in these areas, so that agricultural production can be increased. In this arid and semiarid region, due to water scarcity, it is very difficult to apply the full water requirement of the crop to get maximum growth and yield (Romero et al., 2004). So, it's important to find strategic ways and means to maintain crop yield and growth under water deficit conditions.

Firstly, the subsurface drip irrigation (SDI) is considered as more efficiency method of irrigation for perennial pasture and lucerne (Palacios-Díaz et al., 2009; Kandelous et al., 2012; Lamm et al., 2012; Ismail and Almarshadi, 2013; Montazar et al., 2016). SDI not only reduces the evaporation but also transport the water effectively in the root zone, and as resultant reduce/eliminate the surface runoff and deep seepage (Lamm et al., 2012). Moreover, SDI is considered as the best method because it increases the water use efficiency of lucerne about 20\% compared to furrow irrigation (Hutmacher et al., 2001). The lucerne yield is increased about $20 \%$ with $40 \%$ less irrigation water compared to flood irrigation (Godoy et al., 2003), 7\% more yield with 22\% less irrigation water than sprinkler irrigation (Alam et al., 2002), while compared with border irrigation, subsurface drip irrigation can increase yield by $30 \%$ and water use efficiency by $53 \%$ (Trejo et al., 2010).

Secondly, regulated deficit irrigation (RDI), as a kind of artificial water control, which allows plants to suffer a certain water deficit condition, while maintaining or increasing the crop growth and yield (Fereres and Soriano, 2006; Nunes et al., 2008; Geerts and Raes, 2009; Chen et al., 2014). For pasture, especially lucerne, the study of RDI are scarce and mostly focused on the influence of yield under dry irrigation in the midsummer (Hanson et al., 2007), yield under drought and re-watering during the next period (Kou et al., 2014; Liu et al., 2018), and the impact of seasonal drought on yield (Rogers et al., 2016). A study conducted by Hanson (2007) showed that although the re-watered plants could resume their growth in midsummer under deficit irrigation, no irrigation in July and August resulted in lucerne yield reduction about 4.68-6.47 $\mathrm{Mg} \mathrm{ha}^{-1}$. Kou (2014) reported that although moderate water deficit reduced lucerne yield, late rehydration could compensate part of the yield, it was still lower than non-deficit treatment. Rogers et al. (2016) suggested that the lucerne stand is able to fully recover once a full irrigation regime is resumed during seasonal drought.

So far, the both methods SDI and RDI have been extensively applied separately, in this study we combined both methods to increase the water use efficiency and forage production, and named it regulated deficit drip irrigation (RDDI). The aim of this study was to determine the effects of different regulated deficit irrigation volume under SDI conditions on soil moisture dynamics, yield and quality of lucerne. At the same time, the results of this experiment were compared with the results of the experiment in 2013.

\section{Materials and methods}

\section{Site description}

A field experiment with Lucerne (Medicago sativa L.) was conducted at the Shiyanghe Experimental Station of China Agricultural University at Wuwei, Gansu Province of 
Northwest China (N37 52'20", E102 $50^{\prime} 50^{\prime \prime}$, altitude $1581 \mathrm{~m}$ ) (Figure $\left.1 A\right)$. The site has a typical continental temperate climate with mean sunshine duration of $3000 \mathrm{~h}$, mean annual precipitation of $164.4 \mathrm{~mm}$, pan evaporation of $2000 \mathrm{~mm}$, frost-free period of $150 \mathrm{~d}$ and mean annual temperature of $8.8^{\circ} \mathrm{C}$. Growing-season precipitation and mean temperature daily in 2013 and 2017 are presented in Figure 2. The groundwater table is consistently below $25 \mathrm{~m}$ (Kandelous et al., 2012). The experimental site has a sandy loam soil with average field capacity of $0.29 \mathrm{~cm}^{3} \mathrm{~cm}^{-3}$, soil bulk density of $1.50 \mathrm{~g} \mathrm{~cm}^{-3}$ and a permanent wilting point of $0.12 \mathrm{~cm}^{3} \mathrm{~cm}^{-3}$ in the upper $1 \mathrm{~m}$ of the soil profile.
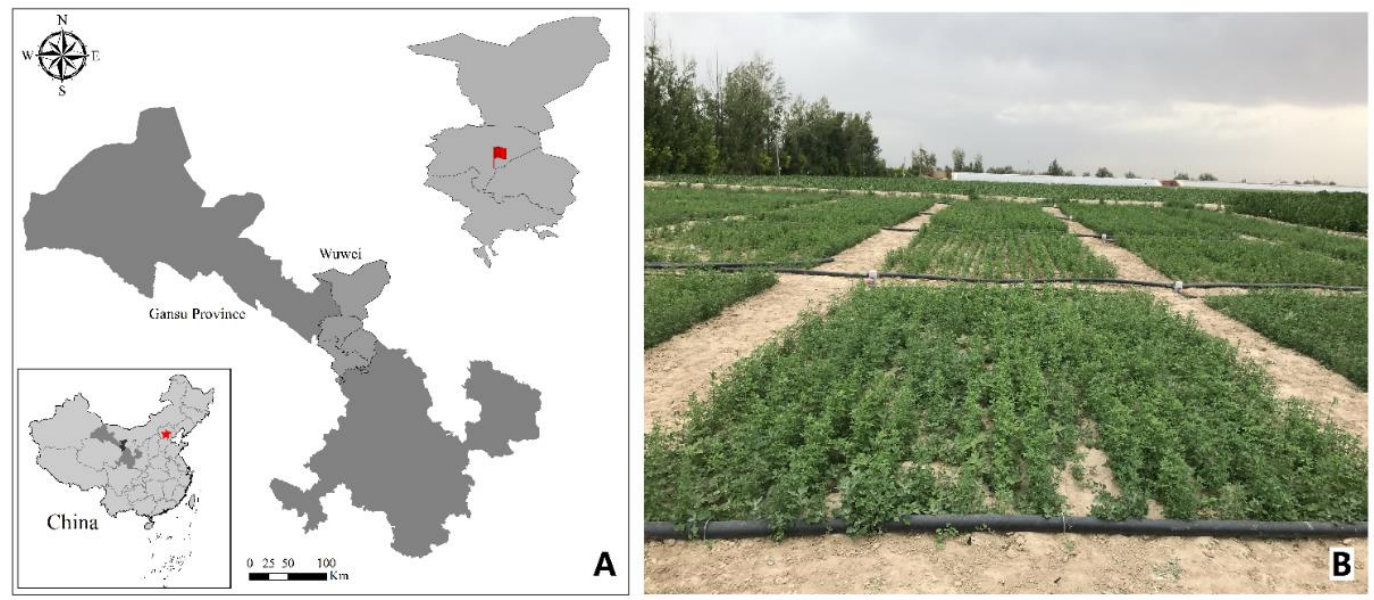

Figure 1. The location of the experimental site (A) and photo of the study site (B)

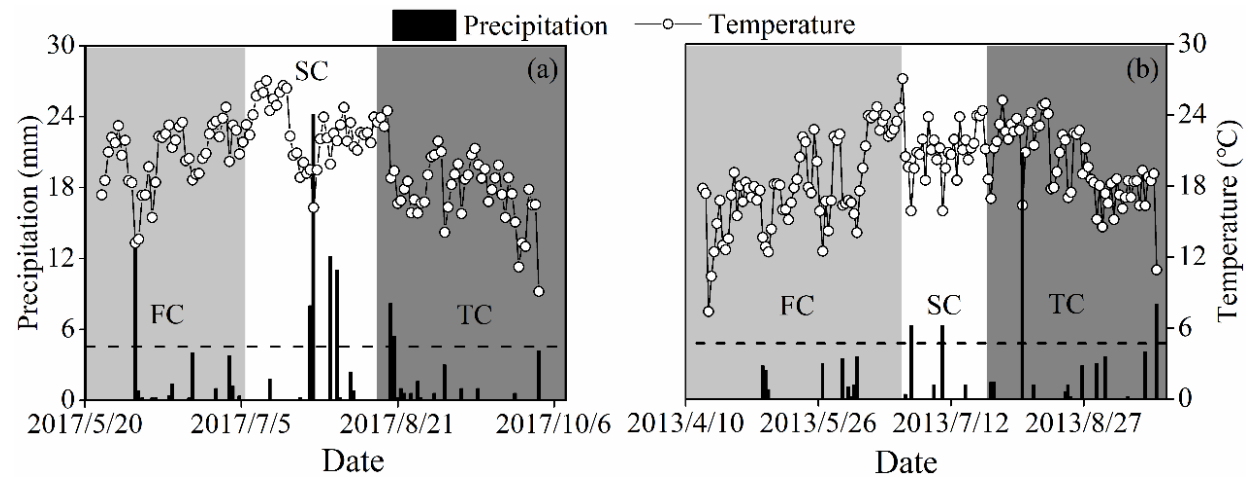

Figure 2. Daily mean temperature and precipitation at the experimental site in 2017 (a) and 2013 (b) at Shiyanghe Experimental Station for Water-saving Agriculture Ecology, China Agricultural University, Wuwei, Gansu Province, China

\section{Experimental design}

In 2013, we conducted the experiment of regulating deficit irrigation for lucerne under SDI in this experimental station, with $30 \mathrm{~cm}$ buried depth of the drip tube, variety Crown, and $22.5 \mathrm{~cm}$ row spacing. The experiment in 2017 adjusted the burying depth of drip irrigation pipe to $20 \mathrm{~cm}$, the spacing between lucerne rows to $20 \mathrm{~cm}$ and the variety of lucerne to 4020 , so as to be closer to the local lucerne production practice. In 2013, the experimental area was $16.2 \mathrm{~m}^{2}(6 \mathrm{~m} \times 2.7 \mathrm{~m})$, and the test area was $24 \mathrm{~m}^{2}(6 \mathrm{~m} \times 4 \mathrm{~m})$ in 2017 (Figure 1B). The plant density was about 600 no. $\mathrm{m}^{-2}$ in the experiment. 
The pressure-compensating emitters with delivery rate at $3 \mathrm{~L} \mathrm{~h}^{-1}$ were spaced at $0.3 \mathrm{~m}$. The irrigation pipes were spaced at $0.9 \mathrm{~m}$ and $0.8 \mathrm{~m}$ in 2012 and 2017. Each irrigation system had their own pond, filtration system (sand and screen mesh), and pipeline network (Dayu water saving group co., ltd., Gansu, China). One drip line controls four rows of lucerne. Four irrigation levels were used with no water deficit (NWD), low water deficit (LWD), medium water deficit (MWD) and high water deficit (HWD), shown in Table 1 and Table 2. The irrigation frequency was fixed to 7 days.

Table 1. Irrigation level and harvest time in the crop management

\begin{tabular}{c|c|c|c|c|c|c}
\hline Stands & Abbreviations & $\begin{array}{c}\text { Designed water levels } \\
(\mathbf{m m})\end{array}$ & $\begin{array}{c}\mathbf{1}^{\text {st. }} \text { cutting } \\
(\mathbf{F C})\end{array}$ & $\begin{array}{c}\mathbf{2}^{\text {nd. }} \text { cutting } \\
(\mathbf{S C})\end{array}$ & $\begin{array}{c}\mathbf{3}^{\text {rd. }} \text { cutting } \\
(\mathbf{T C})\end{array}$ & $\begin{array}{c}\text { Irrigation } \\
\text { time }\end{array}$ \\
\hline \multirow{5}{*}{ annual } & NWD & 390 & & & & \\
& LWD & 260 & $2017 / 7 / 6$ & $2017 / 8 / 17$ & $2017 / 10 / 2$ & 13 \\
& MWD & 130 & & & & \\
\hline \multirow{5}{*}{ biennial } & HWD & 0 & & & & \\
& NWD & 390 & $2013 / 6 / 25$ & $2013 / 7 / 25$ & $2013 / 9 / 5$ & 10 \\
& LWD & 260 & & & & \\
\hline
\end{tabular}

Table 2. Irrigation time and actual irrigation amount in no water deficit (NWD), low water deficit (LWD), medium water deficit (MWD) and high water deficit (HWD) in the experiment

\begin{tabular}{c|c|c|c|c|c}
\hline Irrigation number & Irrigation time & NWD & LWD & MWD & HWD \\
\hline 1 & $2017 / 6 / 17$ & 30 & 20 & 10 & 0 \\
2 & $2017 / 6 / 24$ & 30 & 20 & 10 & 0 \\
3 & $2017 / 7 / 1$ & 30 & 20 & 10 & 0 \\
4 & $2017 / 7 / 8$ & 30 & 20 & 10 & 0 \\
5 & $2017 / 7 / 15$ & 30 & 20 & 10 & 0 \\
6 & $2017 / 7 / 22$ & 30 & 20 & 10 & 0 \\
7 & $2017 / 8 / 5$ & 30 & 20 & 10 & 0 \\
8 & $2017 / 8 / 12$ & 30 & 20 & 10 & 0 \\
9 & $2017 / 8 / 27$ & 30 & 20 & 10 & 0 \\
10 & $2017 / 9 / 3$ & 30 & 20 & 10 & 0 \\
11 & $2017 / 9 / 10$ & 30 & 20 & 10 & 0 \\
12 & $2017 / 9 / 16$ & 30 & 20 & 130 & 0 \\
13 & $2017 / 9 / 23$ & 30 & 20 & 6.00 & 0 \\
Actual irrigation amount (2017) & $2013 / 5 / 15$ & 390 & 260 & 9.24 & 0 \\
1 & $2013 / 5 / 22$ & 15.24 & 11.20 & 28.32 & 0 \\
2 & $2013 / 5 / 29$ & 90.66 & 12.25 & 23.89 & 0 \\
3 & $2013 / 6 / 25$ & 82.89 & 50.14 & 11.05 & 0 \\
4 & $2013 / 7 / 7$ & 39.70 & 23.88 & 14.67 & 0 \\
6 & $2013 / 7 / 17$ & 50.33 & 31.18 & 2.70 & 0 \\
7 & $2013 / 7 / 27$ & 9.18 & 6.08 & 7.08 & 0 \\
8 & $2013 / 8 / 14$ & 24.40 & 15.56 & 8.44 & 0 \\
9 & $2013 / 8 / 14$ & 28.35 & 18.29 & 121.09 & 0 \\
Actual irrigation amount (2013) & 31.05 & 20.32 & & 0 \\
\hline \multicolumn{7}{l}{} & 389.36 & 251.47 & &
\end{tabular}

\section{Sampling and measurements}

\section{Forage yield}

Three lucerne stubbles were harvested $5 \mathrm{~cm}$ above the ground level; $1^{\text {st }}$ cutting (FC), $2^{\text {nd }}$ cutting (SC), and $3^{\text {rd }}$ cutting (TC) at different times interval in the year 2013 and 2017, 
in the early flowering period (Table 1). At each harvest, the forage biomass was cut at ground level from three representative sample quadrats $(1 \mathrm{~m} \times 1 \mathrm{~m})$ in each plot. After the quadrats had been removed, the rest of the plot was cut at the same height as in the quadrats and all the forage samples were oven-dried at $105^{\circ} \mathrm{C}$ for $1 \mathrm{~h}$ and then kept $70^{\circ} \mathrm{C}$ until a constant weight was reached.

\section{Forage qualities}

Dry plant samples were crushed into fine powder and then sieved through $0.5 \mathrm{~mm}$ mesh, and used for the determination of quality attributes like crude protein (CP), acid detergent fibre (ADF) and neutral detergent fibre (NDF). CP (\%) tested by FOSS Kjeltec $^{\mathrm{TM}}$ 8400, then ADF (\%) and NDF (\%) were tested by ANKOM2000 Automated Fiber Analyzer in the bag suspender.

The index of relative feed value (RFV) was calculated by integrating the formulae of (Zhang et al., 2018), to access the forage nutritive value using the forage quality attributes measured by $E q .1$ :

$$
R F V(\%)=[88.9-(0.779 \times A D F(\%))] \times 120 / N D F(\%) \times 0.775
$$

In order to compare the relative nutrition yields amongst the forages accounting for both biomass and forage quality attributes, crude protein yield $\left(\mathrm{CP}_{\text {yield }}\right)$ and relative feed value yield ( $\mathrm{RFV}_{\text {yield }}$ ) were calculated as the product of biomass and $\mathrm{CP}$ concentration and RFV on each sampling occasion by Eq. 2 and 3.

$$
\begin{gathered}
C P_{\text {yield }}\left(k g \bullet h a^{-1}\right)=D M\left(k g \bullet h a^{-1}\right) \times C P(\%) \\
R F V_{\text {yield }}\left(k g \bullet h a^{-1}\right)=D M\left(k g \bullet h a^{-1}\right) \times R F V(\%)
\end{gathered}
$$

\section{Soil moisture, actual crop evapotranspiration and water use efficiency}

Soil moisture measurement in every plot was made at $0.1 \mathrm{~m}$ intervals with maximal soil depth of $1.0 \mathrm{~m}$ at every 3-5 days or before and after irrigation using portable soil moisture monitoring system (Diviner 2000, Sentek Pty. Ltd., Australia). The arrangement of PVC access tubes used for the measurements of soil moisture content were specifically described by (Chen et al., 2014). Calibration was conducted before using the data obtained from Diviner 2000. Soil samples near every tube were acquired at $0.1 \mathrm{~m}$ intervals with maximal soil depth of $1.0 \mathrm{~m}$, and the moisture content of the samples was determined using the gravimetric method (oven dry basis). The ratios of the soil moisture values measured by the gravimetric method to those by Diviner 2000 were used to calibrate the measurements by Diviner 2000. The unit of soil moisture is $\mathrm{cm}^{3} \mathrm{~cm}^{-3}$. The calculation of soil moisture in shallow and deep layers is the average accumulated value of $0-0.4 \mathrm{~m}$ and 0.5-1 m layer. The calibration curves of the relative frequency readings during the twoyear experiment are as follows Equation 4:

$$
\left(F_{A}-F_{S}\right) /\left(F_{A}-F_{W}\right)=0.2869 \times \theta_{V}^{0.3356}
$$


where $F_{A}$ is capacitance frequency reading of probe passing through $\mathrm{PVC}$ tube in air, $F_{S}$ capacitance frequency reading corresponding to a depth of the probe passing through a PVC tube in soil, $F_{W}$ is the capacitance frequency reading of the probe passes through the PVC tube placed in the water and inputs it before calibration of the instrument, $\theta_{\mathrm{v}}$ is soil volumetric moisture.

The actual crop evapotranspiration was estimated with the soil water balance method (Chen et al., 2014). The soil moisture changes in $0-100 \mathrm{~cm}$ soil layer by subsurface drip irrigation over a period time were used to estimate actual crop evapotranspiration with the following Equation 5.

$$
\Delta \mathrm{W}=P+I+S-\left(E T_{a}+D\right)
$$

where $\Delta W$ is the change in soil water storage $(\mathrm{mm}) ; P$ is precipitation (mm), automatic weather station HOBO recorded; I is irrigation water volumes $(\mathrm{mm}) ; S$ is supplement of ground water $(\mathrm{mm}) ; E T_{a}$ is actual crop evapotranspiration $(\mathrm{mm})$ and $D$ is deep percolation $(\mathrm{mm})$. In the experiment site, the contribution of groundwater was negligible because groundwater table is deeper than $25 \mathrm{~m}$, so $S=0$. The subsurface drip system arranged by control irrigation volume in this experiment, so $D=0$. Thus by $E q .6$ can be simplified as follows:

$$
E T_{a}=P+I-\Delta \mathrm{W}
$$

where irrigation water volume was measured using water meters; $\Delta W$ was obtained from soil moisture observations in the $0-1 \mathrm{~m}$ soil layer at the beginning and end of the period. Calculation of $E T_{a}$ at end of each cutting.

Water-use efficiency $\left(\mathrm{kg} \mathrm{mm}^{-1}\right.$ evapotranspiration $\left.\left(E T_{a}\right)\right)$ was calculated for biomass $(W U E ;(E q .7))$, crude protein yield $\left(W U E_{\mathrm{CP}} ;(E q .8)\right)$, and relative feed value yield $\left(W U E_{R F V} ;(E q .9)\right)$ (Zhang et al., 2018):

$$
\begin{gathered}
W U E=D M / E T_{a} \\
W U E_{C P}=C P_{\text {yield }} / E T_{a} \\
W U E_{R F V}=R F V_{\text {yield }} / E T_{a}
\end{gathered}
$$

\section{Statistical analysis}

Analysis of variance (ANOVA) was performed using the general linear modelunivariate procedure from IBM SPSS Statistics 20 software (IBM Corp, AMONG, NY, USA). ANOVAs were done with irrigation volumes and stands years as the main effects and their interaction. Differences for all tests were assessed for significance at $P \leq 0.05$, $P \leq 0.01$ and $P \leq 0.001$; significant differences $(P \leq 0.05)$ between means were identified using the least significant difference (LSD) test. Correlation analyses were used to evaluate the interrelationships among the measured variables. All determinations reported were the means of three replicates. All figures are done using OriginPro 2016 (Originlab Corp, Northampton, Massachusetts, USA) software. 


\section{Results}

\section{Soil moisture dynamics in two years}

Generally speaking, the drying rate near the soil surface is faster and larger than that in the deep soil. In 2017, the variation of soil moisture in the layer of $0-40 \mathrm{~cm}$ was large, because the depth of the burial zone of the drip irrigation tape was $20 \mathrm{~cm}$ to the shallow soil moisture (SM) disturbance (Figure $3 a, b, c, d$ ). Meanwhile, the SM increased with higher trend of irrigation treatment, but it was not obvious in the $1^{\text {st }}$ cutting (FC) (Figure $3 a, b, c, d$ ). At the depth of $40 \mathrm{~cm}$, the SM were slightly higher to the irrigation treatment of medium water deficit (MWD) as compared to the high water deficit (HWD) (Figure 3d). While at the depth of 50-60 cm, the SM in HWD were lower than MWD treatment (Figure 3e). We also observed that with the increase in irrigation volume, SM also increased at the depth of $60 \mathrm{~cm}$ (Figure 3f). In contrast, at the depth of 70-100 cm, the HWD had higher SM than the MWD treatment (Figure $3 g, h, i, j, l$ ). Moderate rain (10-25 mm day ${ }^{-1}$ ) occurred on July 27, 2017, with a precipitation of $24.2 \mathrm{~mm}$. It can be seen that the water content of shallow soil increased rapidly the next day, especially in the surface layer of soil (Figure 3a,b,c,k). In the annual FC of rain-fed (HWD) lucerne soil moisture compensation only occurred on July 27, 2017.
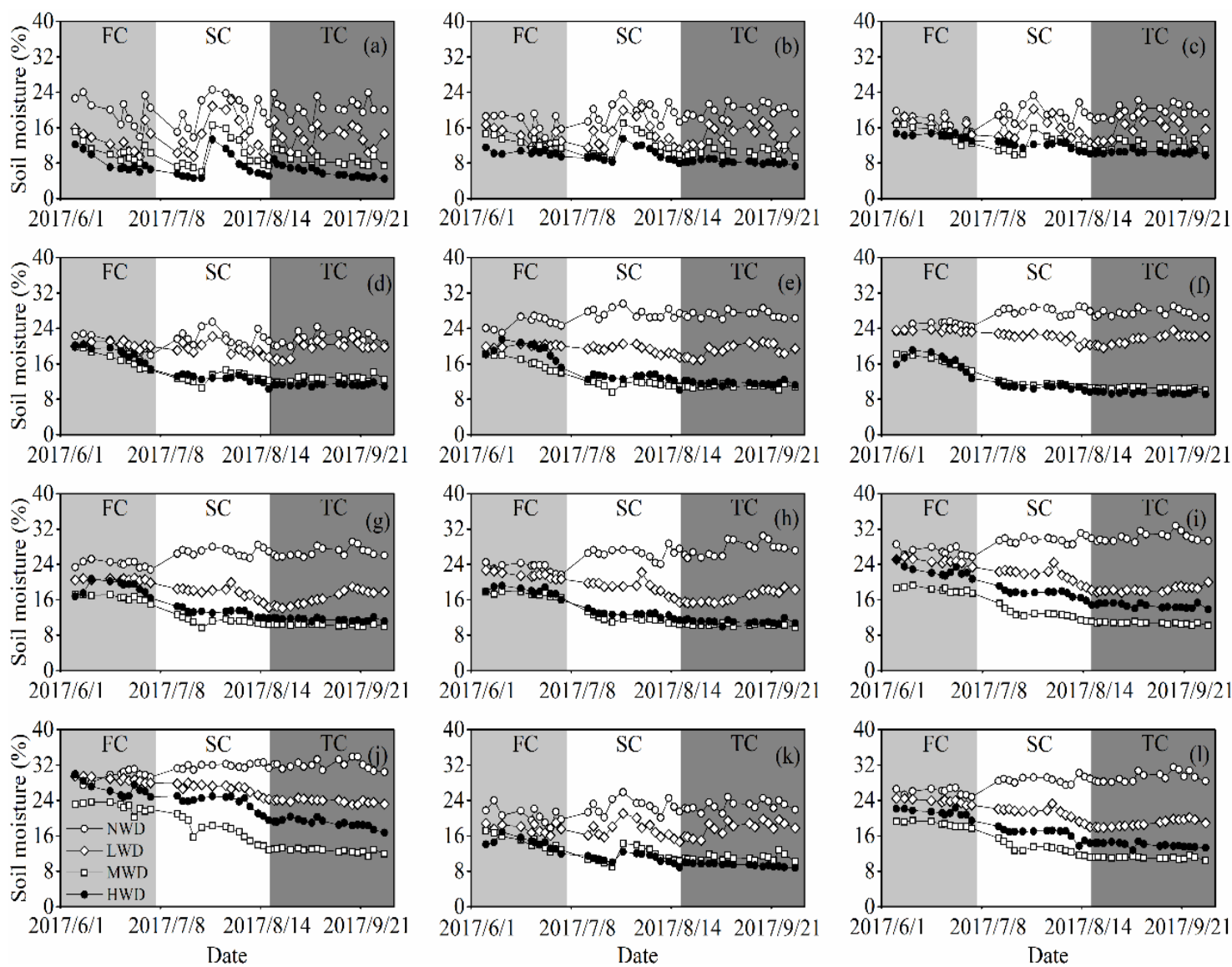

Figure 3. Soil moisture dynamics in the $0-10 \mathrm{~cm}(\mathrm{a}), 10-20 \mathrm{~cm}(\mathrm{~b}), 20-30 \mathrm{~cm}(\mathrm{c}), 30-40 \mathrm{~cm}(\mathrm{~d})$, $40-50 \mathrm{~cm}(\mathrm{e}), 50-60 \mathrm{~cm}(f), 60-70 \mathrm{~cm}(\mathrm{~g}), 70-80 \mathrm{~cm}(\mathrm{~h}), 80-90 \mathrm{~cm}(\mathrm{i}), 90-100 \mathrm{~cm}(\mathrm{j}), 0-60 \mathrm{~cm}(\mathrm{k})$ and $70-100 \mathrm{~cm}$ (l) soil layers in annual lucerne. The light gray area represents the dynamics of soil moisture in the FC, the white area represents the dynamics of soil moisture in the $S C$, and the dark gray area represents the dynamics of soil moisture in the TC 
Compared with the SM of annual lucerne (2017), the SM of the biennial lucerne (2013) also showed dramatic changes in the shallow soil depth 10-40 $\mathrm{cm}$ (Figure 4a,b,c,d,k). Meanwhile, the SM decreased while increasing water deficit conditions in the shallow soil depth 10-50 cm (Figure 4a,b,c,d,e,k). In 60-90 cm depth, HWD had more SM in the FC and $3^{\text {rd }}$ cutting (TC) than that of any treatments (Figure $\left.4 f, g, h, i, l\right)$. In the $2^{\text {nd }}$ cutting (SC), SM of 50-60 cm was negatively correlated with increasing water deficit (Figure $4 f$ ); at 60-70 cm, the SM of HWD were higher than low water deficit (LWD) and medium water deficit (MWD) (Figure 4g); while at 70-90 cm soil layer, HWD had higher SM than MWD (Figure 4h,i,l).
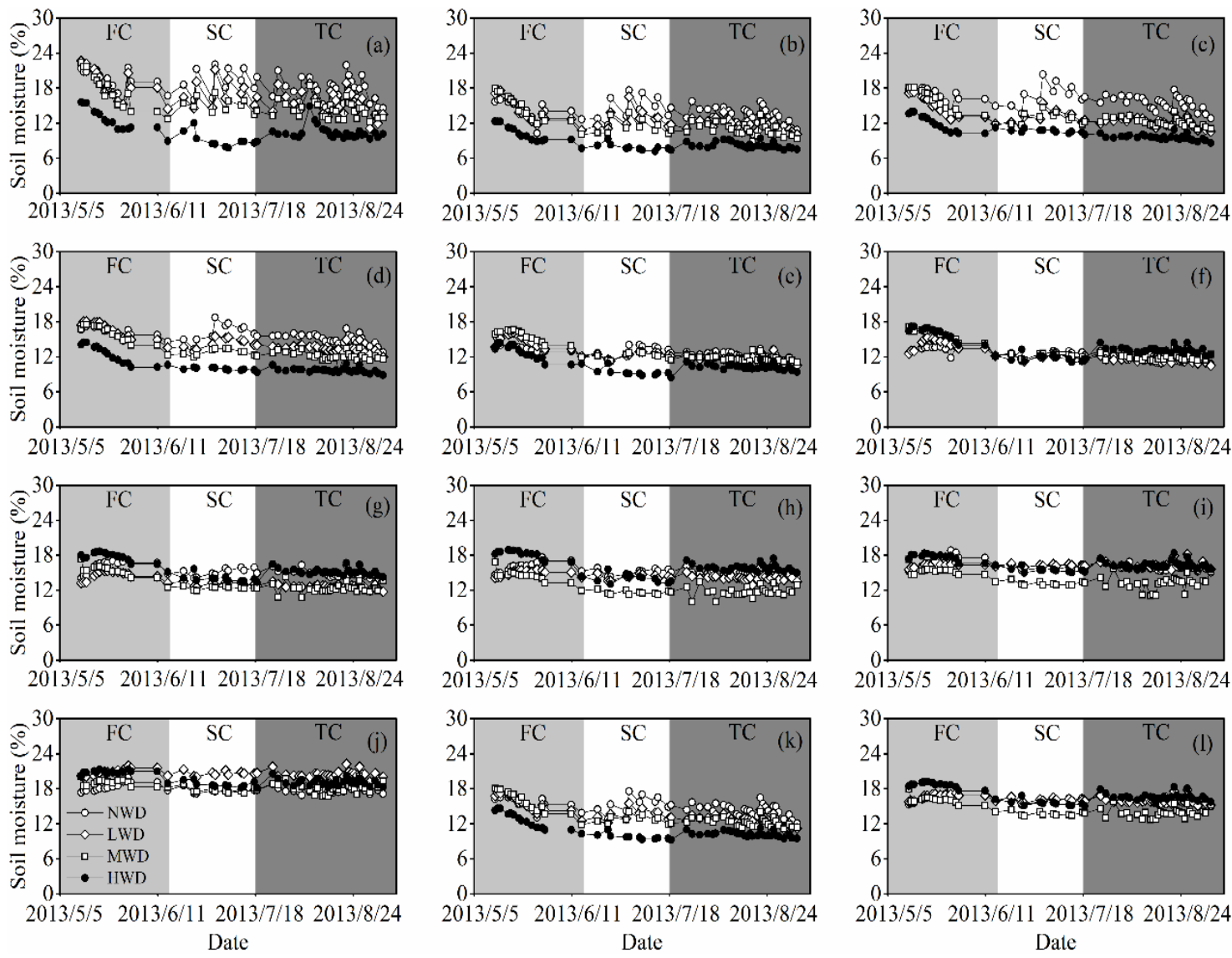

Figure 4. Soil moisture dynamics in the 0-10 cm (a), 10-20 cm (b), 20-30 cm (c), 30-40 cm (d), $40-50 \mathrm{~cm}(\mathrm{e}), 50-60 \mathrm{~cm}(f), 60-70 \mathrm{~cm}(\mathrm{~g}), 70-80 \mathrm{~cm}(\mathrm{~h}), 80-90 \mathrm{~cm}(\mathrm{i}), 90-100 \mathrm{~cm}(\mathrm{j}), 0-60 \mathrm{~cm}(\mathrm{k})$ and 70-100 cm (l) soil layers in biennial lucerne. The light gray area represents the dynamics of soil moisture in the FC, the white area represents the dynamics of soil moisture in the SC, and the dark gray area represents the dynamics of soil moisture in the TC

\section{Forage yield}

The highest mean annual forage yield (12930 kg ha $\mathrm{kg}^{-1}$ ) was recorded with NWD treatment in 2017, and it was higher than biennial lucerne of $2013\left(12165 \mathrm{~kg} \mathrm{ha}^{-1}\right)$, shown in Table 3. Increasing water deficit conditions significantly decreased the forage yield in 2013 and 2017. The forage yield of all treatments was well-fitted $\left(\mathrm{R}^{2}=0.533, P<0.001\right)$ by Pearson's correlation (Table 4). 
Table 3. Forage yield ( $\left.\mathrm{kg} \mathrm{ha}^{-1}\right)$ of annual and biennial lucerne stand age (S) and irrigation volumes (I) at $1^{\text {st. }}$ cutting (FC), $2^{\text {nd. }}$ cutting (SC) and $3^{\text {rd. }}$ cutting (TC)

\begin{tabular}{|c|c|c|c|c|c|}
\hline \multirow{2}{*}{ Stands } & \multirow{2}{*}{ Treatment } & \multicolumn{4}{|c|}{ Forage yield $\left(\mathrm{kg} \mathrm{ha}^{-1}\right)$} \\
\hline & & FC & SC & TC & Annual \\
\hline \multirow{4}{*}{ annual } & HWD & $2752 d$ & $2256 \mathrm{~d}$ & $1556 \mathrm{~d}$ & $6565 d$ \\
\hline & MWD & $3384 \mathrm{c}$ & $2594 \mathrm{~cd}$ & $2696 c$ & $8674 \mathrm{c}$ \\
\hline & LWD & $4425 b$ & $3021 b c$ & $3082 b$ & $10529 b$ \\
\hline & NWD & $5904 \mathrm{a}$ & $3517 \mathrm{ab}$ & $3509 \mathrm{a}$ & $12930 \mathrm{a}$ \\
\hline \multirow{4}{*}{ biennial } & HWD & $3948 b$ & 3236 & $2361 c$ & $9545 d$ \\
\hline & MWD & $4782 \mathrm{a}$ & 3456 & $2612 b c$ & $10850 \mathrm{c}$ \\
\hline & LWD & $5420 \mathrm{a}$ & 3719 & $2862 b c$ & $12000 \mathrm{bc}$ \\
\hline & NWD & $5466 \mathrm{a}$ & 3570 & $3129 \mathrm{ab}$ & $12165 \mathrm{ab}$ \\
\hline \multicolumn{6}{|c|}{ Statistical significance } \\
\hline \multirow{3}{*}{\multicolumn{2}{|c|}{$\begin{array}{c}\text { Stand }(\mathrm{S}) \\
\text { Irrigation volumes(I) } \\
\mathrm{S} \text { *I }\end{array}$}} & $* *$ & $* * *$ & NS & $* * *$ \\
\hline & & $* * *$ & $* *$ & $* * *$ & $* * *$ \\
\hline & & NS & NS & $* *$ & $* *$ \\
\hline
\end{tabular}

Statistical significance: $\mathrm{NS}=$ not significant, ***, and $* * *$ represent $\mathrm{P}<0.05,<0.01$ and $<0.001$, respectively. The lowercase letters indicate significant differences between different irrigation volumes at each year $(\mathrm{P}=0.05)$. The same as below

Table 4. Correlation analysis of lucerne forage yield and qualities with irrigation volumes, $E T_{a}$ and WUEs

\begin{tabular}{c|c|c|c|c|c|c|c}
\hline & forage yield & CP (\%) & NDF (\%) & ADF (\%) & RFV & CP $_{\text {yield }}$ & RFV $_{\text {yield }}$ \\
\hline I & $0.533^{* * * *}$ & $-0.461^{* * *}$ & - & $0.653^{* * * *}$ & $-0.311^{* * *}$ & $0.417^{* * *}$ & $0.256^{*}$ \\
ET & $0.518^{* * *}$ & $-0.256^{*}$ & $0.417^{* * *}$ & $0.733^{* * *}$ & $-0.556^{* * *}$ & $0.539^{* * *}$ & - \\
WUE & - & - & $-0.308^{* *}$ & $-0.5^{* * *}$ & $0.333^{* *}$ & - & - \\
WUECP $_{\text {CUE }}$ & - & - & $-0.426^{* * *}$ & $-0.461^{* * *}$ & $0.499^{* * *}$ & - & - \\
WUE $_{\mathbf{R F V}}$ & $-0.263^{*}$ & - & $-0.522^{* * * *}$ & $-0.609^{* * *}$ & $0.643^{* * *}$ & $-0.312^{* *}$ & - \\
\hline
\end{tabular}

We also found that there was significant difference between the biennial forage yield at HWD and NWD treatments. FC forage yield was highest at each treatment in both annual and biennial lucerne. No significant differences were observed in different treatments of water deficit for the forage yield of SC in 2013, while significant differences were found for TC forage yield at NWD and HWD treatments of biennial lucerne (Table 3).

\section{Lucerne quality}

Crude protein concentration (CP) in forage dry matter was determined and expressed as percentage of crude protein (\%CP) (Table 5). It was found that in biennial lucerne, $\mathrm{CP}$ was decreased with increase in water deficit except FC, while in annual lucerne, $\mathrm{CP}$ was highest at LWD for all cuttings (23.6, 23.6, and 24.29\%) (Table 5). CP was significantly influenced by the lucerne stand age (annual and biennial lucerne) $(P<0.05)$ (Table 5).

In case of Crude protein yield ( $\left.\mathrm{CP}_{\text {yield }}\right)$, the biennial lucerne showed non-significant difference between FC and SC, while TC showed significant difference between HWD and NWD $(P<0.05)$ (Table 5). The annual lucerne showed significant differences among different treatments for $\mathrm{CP}_{\text {yield, }}$, while HWD had the highest $\mathrm{CP}_{\text {yield }}\left(2721 \mathrm{~kg} \mathrm{ha}^{-1}\right)$. The Pearson correlation coefficient between the irrigation treatments and $\mathrm{CP}_{\text {yield }}$ was 0.417 $(P<0.001)$ (Figure 5a, Table 4). 
Table 5. Crude protein content (\%) and Crude protein yield $\left(\mathrm{kg} \mathrm{ha}^{-1}\right)$ of annual and biennial lucerne at $1^{\text {st. }}$ cutting $(F C), 2^{\text {nd. }}$ cutting $(S C)$ and $3^{\text {rd. }}$ cutting (TC)

\begin{tabular}{|c|c|c|c|c|c|c|c|c|}
\hline \multirow{2}{*}{ Stands } & \multirow{2}{*}{ Treatment } & \multicolumn{3}{|c|}{$\mathrm{CP}(\%)$} & \multicolumn{4}{|c|}{$\mathrm{CP}_{\text {yield }}\left(\mathrm{kg} \mathrm{ha}^{-1}\right)$} \\
\hline & & FC & SC & TC & FC & SC & TC & Annual \\
\hline \multirow{4}{*}{ annual } & HWD & $21.92 b$ & $21.92 \mathrm{~b}$ & 22.68 & $841 \mathrm{c}$ & $550 \mathrm{c}$ & $354 d$ & $1745 d$ \\
\hline & MWD & $23.6 \mathrm{a}$ & $23.6 \mathrm{a}$ & 24.29 & $835 c$ & $523 c$ & $654 \mathrm{bc}$ & $2011 \mathrm{c}$ \\
\hline & LWD & $21.32 \mathrm{c}$ & $21.32 \mathrm{c}$ & 21.9 & $954 b$ & $596 b c$ & $675 b c$ & $2224 b$ \\
\hline & NWD & $19.32 \mathrm{~d}$ & $19.32 \mathrm{~d}$ & 24.73 & $1151 \mathrm{a}$ & $703 \mathrm{ab}$ & $868 \mathrm{a}$ & $2721 \mathrm{a}$ \\
\hline \multirow{4}{*}{ biennial } & HWD & 21.41 & $21.31 \mathrm{a}$ & $23.11 \mathrm{ab}$ & $823 b$ & 647 & $539 b$ & $2009 c$ \\
\hline & MWD & 19.75 & $19.26 \mathrm{~b}$ & $22.6 \mathrm{ab}$ & $944 a$ & 665 & $582 \mathrm{ab}$ & $2191 b c$ \\
\hline & LWD & 18.68 & $19.18 \mathrm{~b}$ & $21.92 b c$ & $1012 \mathrm{a}$ & 707 & $620 \mathrm{ab}$ & $2339 \mathrm{ab}$ \\
\hline & NWD & 18.51 & $18.61 \mathrm{~b}$ & $21.25 \mathrm{c}$ & $1012 \mathrm{a}$ & 694 & $666 a$ & $2371 \mathrm{ab}$ \\
\hline \multicolumn{9}{|c|}{ Statistical significance } \\
\hline \multicolumn{2}{|c|}{$\mathrm{S}$} & $* * *$ & $* * *$ & $*$ & NS & $* *$ & NS & $\mathrm{NS}$ \\
\hline \multicolumn{2}{|c|}{ I } & $* * *$ & $* * *$ & NS & $* *$ & NS & $* * *$ & $* * *$ \\
\hline \multicolumn{2}{|c|}{ S*I } & $* * *$ & $* * *$ & NS & NS & NS & $* * *$ & $* *$ \\
\hline
\end{tabular}
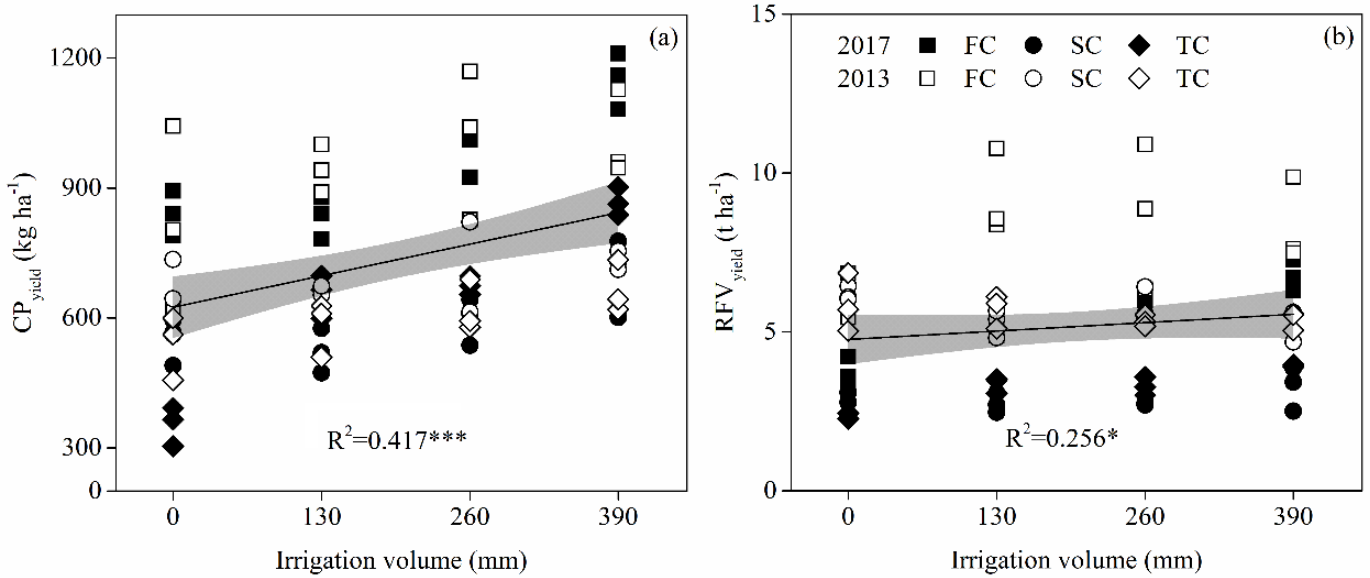

Figure 5. The relationships between (a) irrigation volumes ( $\mathrm{mm}$ ) and $C P_{\text {yield }}\left(\mathrm{kg} \mathrm{ha}^{-1}\right)$, (b) irrigation volumes $(\mathrm{mm})$ and $R F V_{\text {yield }}\left(t \mathrm{ha}^{-1}\right)$ under four irrigation volumes $(0 \mathrm{~mm}, 130 \mathrm{~mm}$, $260 \mathrm{~mm}, 390 \mathrm{~mm})$. The significant linear regression equations are shown, $* P<0.05$, $* * P<0.01, * * * P<0.001$

Acid detergent fibre (ADF \%) and neutral detergent fibre (NDF \%) were significantly influenced by the lucerne stands age (annual and biennial lucerne) $(P<0.05)$ and irrigation volumes $(\mathrm{I})(P<0.001)$ (Table 6$)$. These were increased with the increase in water deficit except for ADF in TC and NDF in FC of annual lucerne. The lower ADF and NDF, the better the forage digestibility, thus, water deficit might improve forage digestibility by reducing ADF and NDF.

The trend in relative feed value (RFV) was directly correlated with the lucerne stand age $(\mathrm{S})$ and irrigation volume (I) $(P<0.001)$ (Table 4). Lucerne stands with NWD showed lower RFV, compared with other irrigation treatments except at LWD of TC of annual lucerne (Table 7). There was no significant difference between SC of annual lucerne and $\mathrm{TC}$ of biennial lucerne in the relative feed value yield $\left(\mathrm{RFV}_{\text {yield }}\right)($ Table 7$)$, but the annual lucerne $\mathrm{RFV}_{\text {yield }}$ was significantly positively correlated to irrigation volumes $(P<0.01)$ (Figure $5 b$ ). The annual RFV yield was increased by $35.9 \%$ and $4.14 \%$ at HWD compared with NWD in annual and biennial lucerne respectively (Table 7). 
Table 6. ADF (\%) and ADF (\%) of annual and biennial lucerne at $1^{\text {st. }}$ cutting $(F C), 2^{\text {nd. }}$ cutting (SC) and $3^{\text {rd. }}$ cutting (TC)

\begin{tabular}{|c|c|c|c|c|c|c|c|}
\hline \multirow{2}{*}{ Stands } & \multirow{2}{*}{ Treatment } & \multicolumn{3}{|c|}{ ADF (\%) } & \multicolumn{3}{|c|}{ NDF (\%) } \\
\hline & & FC & SC & TC & FC & SC & TC \\
\hline \multirow{4}{*}{ annual } & HWD & $27.91 d$ & $20.8 \mathrm{~d}$ & $22.52 \mathrm{c}$ & $46.14 \mathrm{ab}$ & 51.57 & $43.34 b$ \\
\hline & MWD & $28.79 \mathrm{~cd}$ & $32.12 b c$ & $25.09 \mathrm{~b}$ & $43.22 b$ & 56.1 & $52.01 \mathrm{a}$ \\
\hline & LWD & $31.13 b c$ & $34.07 \mathrm{bc}$ & $31.45 \mathrm{a}$ & $46.03 \mathrm{ab}$ & 62.27 & $56.37 \mathrm{a}$ \\
\hline & NWD & $33.7 \mathrm{ab}$ & $35.42 \mathrm{ab}$ & $29.68 \mathrm{a}$ & $48.58 \mathrm{a}$ & 62.32 & $54.53 \mathrm{a}$ \\
\hline \multirow{4}{*}{ biennial } & HWD & 24.44 & $24.69 \mathrm{c}$ & $19.9 \mathrm{~d}$ & 34.14 & $33.8 \mathrm{~d}$ & $27.65 c$ \\
\hline & MWD & 27.98 & $28.39 b$ & $22.97 \mathrm{c}$ & 35.4 & $38.35 \mathrm{c}$ & $29.45 c$ \\
\hline & LWD & 28.9 & $29.5 b$ & $25.46 \mathrm{~b}$ & 39 & $39.99 b c$ & $32.96 \mathrm{~b}$ \\
\hline & NWD & 30.75 & $32.33 \mathrm{a}$ & $29.17 \mathrm{a}$ & 39.7 & $41.69 \mathrm{ab}$ & $37.07 \mathrm{a}$ \\
\hline \multicolumn{8}{|c|}{ Statistical significance } \\
\hline & $S$ & $* *$ & $*$ & $* * *$ & $* * *$ & $* * *$ & $* * *$ \\
\hline & I & $* * *$ & $* * *$ & $* * *$ & $* *$ & $* *$ & $* * *$ \\
\hline & $* \mathrm{I}$ & NS & $* *$ & $* * *$ & NS & NS & $* *$ \\
\hline
\end{tabular}

Table 7. RFV (\%) and RFV yield $\left(t h a^{-1}\right)$ of annual and biennial lucerne at $1^{\text {st. }}$ cutting $(F C), 2^{\text {nd. }}$ cutting (SC) and $3^{\text {rd. }}$ cutting (TC)

\begin{tabular}{|c|c|c|c|c|c|c|c|c|}
\hline \multirow{2}{*}{ Stands } & \multirow{2}{*}{ Treatment } & \multicolumn{3}{|c|}{ RFV } & \multicolumn{4}{|c|}{$\operatorname{RFV}_{\text {yield }}\left(\mathrm{t} \mathrm{ha}^{-1}\right)$} \\
\hline & & FC & SC & TC & FC & SC & TC & Annual \\
\hline \multirow{4}{*}{ annual } & HWD & $135.39 \mathrm{ab}$ & $132.66 \mathrm{a}$ & $153.29 a$ & $3.73 c$ & 2.94 & $2.39 \mathrm{c}$ & $8.89 \mathrm{c}$ \\
\hline & MWD & $143.45 \mathrm{a}$ & $106.44 \mathrm{ab}$ & $124.36 \mathrm{a}$ & $5.3 b$ & 2.76 & $3.35 b$ & $11.39 \mathrm{~b}$ \\
\hline & LWD & $130.89 \mathrm{ab}$ & $93.22 \mathrm{abc}$ & $106.5 b$ & $5.63 \mathrm{ab}$ & 2.82 & $3.29 b$ & $11.71 \mathrm{~b}$ \\
\hline & NWD & $120.42 b$ & $92.67 \mathrm{c}$ & $112.25 \mathrm{c}$ & $6.76 \mathrm{a}$ & 3.26 & $3.94 \mathrm{a}$ & $13.87 \mathrm{a}$ \\
\hline \multirow{4}{*}{ biennial } & HWD & $190.36 \mathrm{a}$ & $192.48 \mathrm{a}$ & $248.14 \mathrm{a}$ & $5.95 b$ & $6.19 a$ & 5.86 & $18.29 \mathrm{~b}$ \\
\hline & MWD & $182.84 \mathrm{ab}$ & $162.17 \mathrm{bc}$ & $224.27 b$ & $9.24 \mathrm{a}$ & $5.29 \mathrm{~b}$ & 5.7 & $20.59 \mathrm{a}$ \\
\hline & LWD & $158.85 \mathrm{bc}$ & $153.76 \mathrm{~cd}$ & $195.79 \mathrm{c}$ & $8.7 \mathrm{ab}$ & $5.8 \mathrm{ab}$ & 5.35 & $20.23 \mathrm{ab}$ \\
\hline & NWD & $151.65 \mathrm{~cd}$ & $142.32 \mathrm{~d}$ & $166.27 \mathrm{~d}$ & $8.32 \mathrm{ab}$ & $5.3 \mathrm{~b}$ & 5.38 & $19.08 \mathrm{ab}$ \\
\hline \multicolumn{9}{|c|}{ Statistical significance } \\
\hline \multicolumn{2}{|c|}{$S$} & $* * *$ & $* * *$ & $* * *$ & $* * *$ & $* * *$ & $* * *$ & $* * *$ \\
\hline \multicolumn{2}{|c|}{ I } & $* * *$ & $* * *$ & $* * *$ & $* *$ & NS & NS & $* *$ \\
\hline \multicolumn{2}{|c|}{$\mathrm{S} * \mathrm{I}$} & NS & NS & $* *$ & NS & NS & $* *$ & $*$ \\
\hline
\end{tabular}

\section{Correlations among forage yield and qualities with irrigation volume, ET and WUEs}

The forage yield, $\mathrm{CP}_{\text {yield }}$ and $\mathrm{RFV}_{\text {yield }}$ were positively correlated with the irrigation volume (I), and the correlation coefficients were $0.533(P<0.001), 0.417(P<0.001)$ and $0.235(P<0.05)$, respectively (Table 4$)$. The forage yield and $\mathrm{CP}_{\text {yield }}$ showed significant positive correlation with actual crop evapotranspiration $\left(\mathrm{ET}_{\mathrm{a}}\right)$, but significant negative correlation with WUERF (Table 4, Figure 6).

There was no correlation between NDF and irrigation volume (I), CP and WUEs (Including WUE, WUE $E_{\mathrm{CP}}$ and $\mathrm{WUE}_{\mathrm{RFV}}$ ). We found some interesting information in Table 7. First, $\mathrm{CP}$ has a negative correlation with $\mathrm{I}$ and $\mathrm{ET}_{\mathrm{a}}$, and the correlation coefficients were $-0.461(P<0.001)$ and $-0.256(P<0.05)$, respectively. Secondly, not only NDF positive correlation with $\mathrm{ET}_{\mathrm{a}}$, it also had significant negative correlation with WUEs. Third, ADF had a positive correlation with I and $\mathrm{ET}_{\mathrm{a}}$, but it was also negatively correlated with WUEs. Last, RFV, in contrast to NDF and ADF, showed a negative correlation with I and $\mathrm{ET}_{\mathrm{a}}$, but significantly and positively correlated with WUEs. 

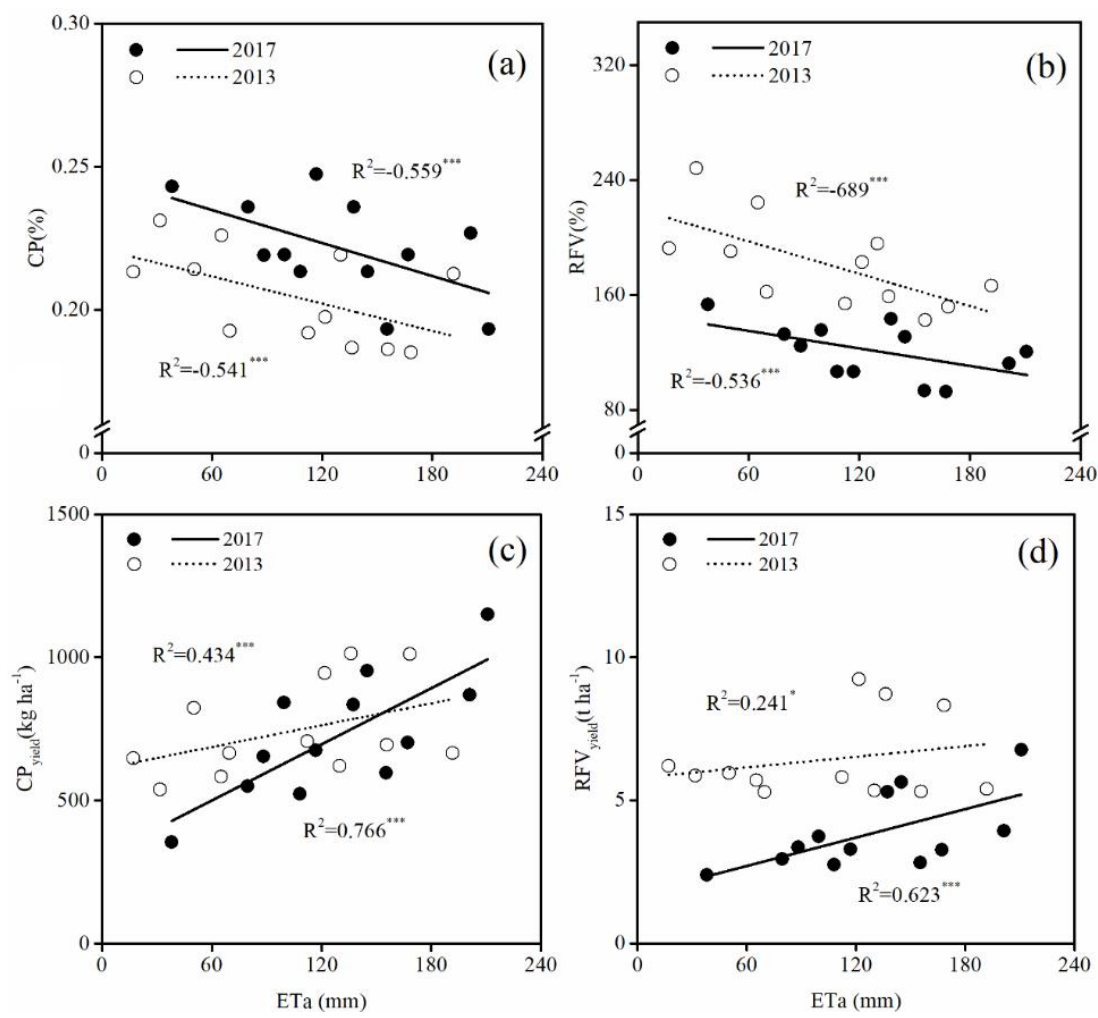

Figure 6. The relationships between (a) $E T_{a}(\mathrm{~mm})$ and $C P(\%)$, (b) $E T_{a}(\mathrm{~mm})$ and $R F V(\%)$, (c) $E T_{a}(\mathrm{~mm})$ and $C P_{\text {yield }}\left(\mathrm{kg} \mathrm{ha}^{-1}\right)$, (d) $E T_{a}(\mathrm{~mm})$ and $R F V_{\text {yield }}\left(t \mathrm{ha} \mathrm{a}^{-1}\right)$. The significant linear regression equations are shown, ${ }^{*} P<0.05,{ }^{*} P P<0.01, * * * P<0.001$

\section{Discussion}

The Hexi Corridor has been characterized by extreme water shortage, and thus water availability is insufficient to satisfy crop water consumption. So many water-saving methods were proposed to improve the local crop water utilization efficiency, such as drip irrigation under plastic film mulch, regulated deficit irrigation (RDI), partial rootzone irrigation and subsurface drip irrigation. These technologies play an important role in water-saving irrigation cultivation in Hexi Corridor. Subsurface drip irrigation has been proven to improve water use efficiency of pasture (Kandelous et al., 2012), and be able to obtain greater investment return on lucerne (Heard et al., 2012). The possible reason is the water absorption layer of the root system is distributed in the shallow region (Bai and Li, 2003; Ayars et al., 2009; Kandelous et al., 2012). The subsurface drip irrigation system transports water around the main absorbent roots of lucerne to ensure greater water use efficiency. So that soil moisture in the soil layer of $0-40 \mathrm{~cm}$ changed greatly (Figure 3a,b,c,d and Figure 4a,b,c,d). Although surface evaporation can also reduce soil moisture, at this time, because lucerne almost completely covers the ground, ground evaporation almost not be considered. Therefore, the variation of shallow soil moisture is mainly caused by root water absorption (Bai and $\mathrm{Li}, 2003$ ). In addition, irrigation water is supplied to lucerne shallow root-zone by capillary movement from the bottom. Infiltration movement induces plant hardening or internal physiological regulations caused by mild water stress (Chai et al., 2016). This perennial pasture, which can be mowed many times in one year, is in good agreement with the properties of SDI system. 
On the other hand, RDI is often applied to pasture as an irrigation strategy in arid areas (Hanson et al., 2007; Geerts and Raes, 2009; Neal et al., 2012; Liu et al., 2018), it usually shows a certain compensation effect after rehydration (Geerts and Raes, 2009; Liu et al., 2018). It is also possible to induce a super compensation effect in the time of water insensitivity (Zhou et al., 2011; Albasha et al., 2015). The results of this experiment showed that RDI decreased the yield of lucerne (Table 3), but increased the quality of lucerne (Tables 5 and 6). The annual lucerne yield was $6565-12930 \mathrm{~kg} \mathrm{ha}^{-1}$ and $9545-12165 \mathrm{~kg} \mathrm{ha}^{-1}$ in the biennial lucerne, is in the high range of reported from semiarid areas (Bai and Li, 2003; Li and Huang, 2008; Lamm et al., 2012; Ismail et al., 2013; Klonie et al., 2013; Xiao et al., 2015; Holman et al., 2016; Rogers et al., 2016; Anower et al., 2017; Cavero et al., 2017; Li and Su, 2017; Huang et al., 2018; Liu et al., 2018). Different from many other studies of lucerne yield, the yield of annual lucerne is almost the same as that of biennial lucerne. The reason for this may be that we harvested three cuttings in the second year of our experiment as well as in the first year. Unlike other crops, lucerne is harvested as a nutrient, while the general field crops harvest seeds or fruit production (Kang et al., 2000; Chen et al., 2014; Du et al., 2016; Yang et al., 2017). The redundant growth of crops can be reduced more or less by RDI on those crops (Kang et al., 2000; Du et al., 2016; Yang et al., 2017). But lucerne harvest is aboveground biomass, the more vigorous the plant growth, the higher the yield we get. There is a positive correlation between the volume of irrigation and the forage yield (Figure 2), which is consistent with the study of many predecessors (Bai and Li, 2003; Klonie et al., 2013; Holman et al., 2016), except for excessive irrigation research (Xiao et al., 2015; Cavero et al., 2017).

There is a positive correlation between irrigation and evapotranspiration of lucerne (Saeed and El-Nadi, 1997; Klocke et al., 2013; Li and Su, 2017), while photosynthetic assimilates accumulated more to yield (Mouradi et al., 2016; Anower et al., 2017). This paper also showed a positive correlation between forage evapotranspiration and forage yield $(P<0.001)$ (Table 4$)$. Studies in this region also suggest that lucerne evapotranspiration is around $400 \mathrm{~mm}$ ( $\mathrm{Li}$ and $\mathrm{Su}, 2017$ ), and the maximum volume of water set in this experiment is $390 \mathrm{~mm}$.

In our experiment, especially CP yield and RFV yield are positively correlated with irrigation volume. Though irrigation volume negative correlation with RFV, RFV yield value is the product of RFV and yield of lucerne, which largely offset the negative correlation of RFV. In addition to NDF (\%), there was a significant correlation between the quality indexes and the irrigation volumes (Figure 5, Table 4). In particular, the second-year stand forage $\mathrm{CP}(\%)$ has a negative correlation with the volume of irrigation, which can be explained as the water deficit increase the pasture $\mathrm{CP}(\%)$. The results showed that RFV has a negative correlation with the volumes of irrigation, and it can also be consistent with the previous conclusion (Harmoney et al., 2013; Holman et al., 2016).

$\mathrm{CP}(\%)$ and RFV were not the decisive factors for forage quality. Quality yield depends on the forage yield, forming two important quality indexes, namely, $\mathrm{CP}_{\text {yield }}$ and $\mathrm{RFV}_{\text {yield. }}$ In this study, the correlation coefficient between irrigation volume and $\mathrm{CP}_{\text {yield }}, \mathrm{RFV}_{\text {yield }}$ was $0.417(P<0.001)$ and $0.256(P<0.05)$, respectively (Figure 5 and Table 4$)$. Therefore, with the increase of the volume of irrigation, $\mathrm{CP}_{\text {yield }}$ and $\mathrm{RFV}_{\text {yield }}$ tend to increase. The reason is largely because the contribution of the irrigation volumes to the yield is greater than that of the quality. That is to say, the regulated deficit irrigation can improve the quality of lucerne, but it is based on the decline of yield (Holman et al., 2016). In the irrigation treatment MWD $(260 \mathrm{~mm})$, the output of the first year and second years 
decreased by $18.57 \%$ and $1.37 \%$ compared with the irrigation treatment of NWD $(390 \mathrm{~mm})$ (Table 2). It shows that the influence of irrigation volume on yield decreases with the increase of year. The $\mathrm{CP}_{\text {yield }}$ decreased by $18.27 \%$ in the same case for the first year, and $1.35 \%$ in second years. $\mathrm{RFV}_{\text {yield }}$ decreased by $15.57 \%$ in the first year with the same treatment, while second years showed an increase of $6.03 \%$. We could know that pasture is sensitive to water in the first year, so it can be fully irrigated, while moderate deficit in second years is more conducive to the formation of forage $\mathrm{RFV}_{\text {yield. Another }}$ study in Gansu showed that forage in this area $\mathrm{CP}_{\text {yield }}$ swung between $360-1200 \mathrm{~kg} \mathrm{ha}^{-1}$ and $\mathrm{RFV}_{\text {yield }}$ was between 1-9.5 $\mathrm{t} \mathrm{ha}^{-1}$ (Zhang et al., 2018). In this experiment, the $\mathrm{CP}_{\text {yield }}$ of annual forage under no irrigation is $1,745 \mathrm{~kg}$, and the next year's $\mathrm{CP}_{\text {yield }}$ is higher than that of annual pasture (Table 5). Under the same conditions, the first year of $\mathrm{RFV}_{\text {yield }}$ was $8.89 \mathrm{tha}^{-1}, 18.29 \mathrm{t} \mathrm{ha}^{-1}$ for the biennial forage (Table 7). The $\mathrm{CP}_{\text {yield }}$ was much higher than the other pasture although the annual $\mathrm{RFV}_{\text {yield }}$ was lower than the highest $\mathrm{RFV}_{\text {yield }}$ of maize. Thus, lucerne is undoubtedly the most valuable pasture, whether it is the development of grassland agriculture, or the development of cultivated forage.

\section{Conclusion}

The drying rate near the soil surface is faster and larger than that in the deep soil. The water content of deep soil is higher than that of shallow soil. $60 \mathrm{~cm}$ of subsurface dripirrigated lucerne can be considered as the diagnostic layer of water deficit. This study showed that regulated deficit drip irrigation reduced forage yield, but increased quality content and water use efficiency of lucerne. Recommends no deficit in the first year, and moderate water deficit in second year in the practical cultivation and irrigation of lucerne.

Acknowledgments. This research was supported by National Key Research and Development Program of China (2016YFC0400306). The authors thank for Liliang Han's help, staff member of Shiyanghe Experimental Station Liang Zhang and Quan Lu for help of the field trial in 2013 and 2017.

\section{REFERENCES}

[1] Alam, M., Trooien, T. P., Rogers, D. H., Dumler, T. J. (2002): Using subsurface drip irrigation for alfalfa. - Journal of the American Water Resources Association 38: 17151721.

[2] Albasha, R., Mailhol, J., Cheviron, B. (2015): Compensatory uptake functions in empirical macroscopic root water uptake models - Experimental and numerical analysis. Agricultural Water Management 155: 22-39.

[3] Anower, M. R., Boe, A., Auger, D., Mott, I. W., Peel, M. D., Xu, L., Kanchupati, P., Wu, Y. (2017): Comparative drought response in eleven diverse alfalfa accessions. - Journal of Agronomy and Crop Science 203: 1-13.

[4] Ayars, J. E., Shouse, P., Lesch, S. M. (2009): In situ use of groundwater by alfalfa. Agricultural Water Management 96: 1579-1586.

[5] Bai, W., Li, L. (2003): Effect of irrigation methods and quota on root water uptake and biomass of alfalfa in the Wulanbuhe sandy region of China. - Agricultural Water Management 62: 139-148.

[6] Bouton, J. H. (2012): An overview of the role of lucerne (Medicago sativa L.) in pastoral agriculture. - Crop and Pasture Science 63: 734-738. 
[7] Cavero, J., Faci, J. M., Medina, E. T., Martínez-Cob, A. (2017): Alfalfa forage production under solid-set sprinkler irrigation in a semiarid climate. - Agricultural Water Management 191: 184-192.

[8] Chai, Q., Gan, Y., Zhao, C., Xu, H., Waskom, R. M., Niu, Y., Kadambot, H. M. (2016): Regulated deficit irrigation for crop production under drought stress. A review. Agronomy for Sustainable Development 36: 3.

[9] Chen, J., Kang, S., Du, T., Guo, P., Qiu, R., Chen, R., Gu, F. (2014): Modeling relations of tomato yield and fruit quality with water deficit at different growth stages under greenhouse condition. - Agricultural Water Management 146: 131-148.

[10] Du, S., Kang, S., Li, F., Du, T. (2016): Water use efficiency is improved by alternate partial root-zone irrigation of apple in arid northwest China. - Agricultural Water Management 179: 184-192.

[11] Fereres, E., Soriano, M. A. (2006): Deficit irrigation for reducing agricultural water use. Journal of Experimental Botany 58: 147-159.

[12] Geerts, S., Raes, D. (2009): Deficit irrigation as an on-farm strategy to maximize crop water productivity in dry areas. - Agricultural Water Management 96: 1275-1284.

[13] Godoy, A. C., Pérez, G. A., Torres, E. C. A., Hermosillo, L. J., Reyes, J. (2003): Water use, forage production and water relations in alfalfa with subsurface drip irrigation. Agrociencia-Mexico 37: 107-115.

[14] Hanson, B., Putnam, D., Snyder, R. (2007): Deficit irrigation of alfalfa as a strategy for providing water for water-short areas. - Agricultural Water Management 93: 73-80.

[15] Harmoney, K. R., Lamm, F. R., Johnson, S. K., Aboukheira, A. A. (2013): Reducing water inputs with subsurface drip irrigation may improve alfalfa nutritive value. - Forage and Grazinglands 11(1): 1-8.

[16] Heard, J. W., Porker, M. J., Armstrong, D. P., Finger, L., Ho, C. K. M., Wales, W. J., Malcolm, B. (2012): The economics of subsurface drip irrigation on perennial pastures and fodder production in Australia. - Agricultural Water Management 111: 68-78.

[17] Holman, J., Min, D., Klonie, N., Kisekka, I., Currie, R. (2016): Effects of irrigation amount and timing on alfalfa nutritive value. - Transactions of the ASABE 59: 849-860.

[18] Huang, Z., Liu, Y., Cui, Z., Fang, Y., He, H., Liu, B., Wu, G. (2018): Soil water storage deficit of alfalfa (Medicago sativa) grasslands along ages in arid area (China). - Field Crops Research 221: 1-6.

[19] Hutmacher, R. B., Phene, C. J., Mead, R. M., Jobes, J. (2001): Subsurface drip and furrow irrigation comparison with alfalfa in the Imperial Valley, California. - Alfalfa \& Forage Symposium, Modesto, CA.

[20] Ismail, S., Almarshadi, M. (2013): Maximizing productivity and water use efficiency of alfalfa under precise subsurface drip irrigation in arid regions. - Irrigation and Drainage 62: 57-66.

[21] Kandelous, M. M., Kamai, T., Vrugt, J. A., Šimůnek, J., Hanson, B., Hopmans, J. W. (2012): Evaluation of subsurface drip irrigation design and management parameters for alfalfa. - Agricultural Water Management 109: 81-93.

[22] Kang, S., Shi, W., Zhang, J. (2000): An improved water-use efficiency for maize grown under regulated deficit irrigation. - Field Crops Research 67: 207-214.

[23] Klocke, N. L., Currie, R. S., Holman, J. D. (2013): Alfalfa response to irrigation from limited water supplies. - Transactions of the ASABE 56: 1759-1768.

[24] Kou, D., Su, D., Wu, D., Li, Y. (2014): Effects of regulated deficit irrigation on water consumption, hay yield and quality of alfalfa under subsurface drip irrigation. Transactions of the Chinese Society of Agricultural Engineering 30: 116-123. (in Chinese with English abstract).

[25] Lamm, F. R., Harmoney, K. R., Aboukheira, A. A., Johnson, S. K. (2012): Alfalfa production with subsurface drip irrigation in the Central Great Plains. - Transactions of the ASABE 55: 1203-1212. 
[26] Li, Y., Huang, M. (2008): Pasture yield and soil water depletion of continuous growing alfalfa in the Loess Plateau of China. - Agriculture, Ecosystems \& Environment 124: 2432.

[27] Li, Y., Su, D. (2017): Alfalfa Water Use and Yield under Different Sprinkler Irrigation Regimes in North Arid Regions of China. - Sustainability-Basel 9: 1380.

[28] Lin, H., Li, R., Liu, Y., Zhang, J., Ren, J. (2017): Allocation of grassland, livestock and arable based on the spatial and temporal analysis for food demand in China. - Front. of Agric. Sci. and Eng 4: 69-80.

[29] Liu, Y., Wu, Q., Ge, G., Han, G., Jia, Y. (2018): Influence of drought stress on alfalfa yields and nutritional composition. - BMC Plant Biology 18: 13.

[30] Montazar, A., Zaccaria, D., Bali, K., Putnam, D. (2016): A model to assess the economic viability of alfalfa production under subsurface drip irrigation in California. - Irrigation and Drainage 66(1): 90-102.

[31] Mouradi, M., Farissi, M., Bouizgaren, A., Makoudi, B., Kabbadj, A. (2016): Effects of water deficit on growth nodulation and physiological and biochemical processes in Medicago sativa rhizobia symbiotic association. - Arid Land Research \& Management 30: 193-208.

[32] Neal, J. S., Murphy, S. R., Harden, S., Fulkerson, W. J. (2012): Differences in soil water content between perennial and annual forages and crops grown under deficit irrigation and used by the dairy industry. - Field Crops Research 137: 148-162.

[33] Nunes, C., de Sousa Araújo, S., Da Silva, J. M., Fevereiro, M. P. S., da Silva, A. B. (2008): Physiological responses of the legume model Medicago truncatula cv. Jemalong to water deficit. - Environmental and Experimental Botany 63: 289-296.

[34] Palacios-Díaz, M. P., Mendoza-Grimón, V., Fernández-Vera, J. R., Rodríguez-Rodríguez, F., Tejedor-Junco, M. T., Hernández-Moreno, J. M. (2009): Subsurface drip irrigation and reclaimed water quality effects on phosphorus and salinity distribution and forage production. - Agricultural Water Management 96: 1659-1666.

[35] Rogers, M. E., Lawson, A. R., Kelly, K. B. (2016): Lucerne yield, water productivity and persistence under variable and restricted irrigation strategies. - Crop and Pasture Science 67: 563-573.

[36] Romero, P., Botia, P., Garcia, F. (2004): Effects of regulated deficit irrigation under subsurface drip irrigation conditions on water relations of mature almond trees. - Plant and Soil 260: 155-168.

[37] Trejo, M., Aguilu, A., Ramirez, O., Lopez, R., Gonzalez, R., Rangel, P., Trejo, M., Castruita, S., Vidal, O., Coronado, Y. (2010): Uso del agua en la alfalfa (Medicago sativa) con riego por goteo subsuperficial. - Revista Mexicana de ciencias pecuarias 1(2): 145156.

[38] Xiao, Y., Zhang, J., Jia, T. T., Pang, X. P., Guo, Z. G. (2015): Effects of alternate furrow irrigation on the biomass and quality of alfalfa (Medicago sativa). - Agricultural Water Management 161: 147-154.

[39] Xu, R., Ren, J., Nan, Z., Huang, J., Deng, X., Lin, H., Qiu, H. (2016): Strategies and policies for the ecological and food security of China's grassland. - Engineering Science 18: 8-16. (in Chinese with English abstract).

[40] Yang, H., Du, T., Qiu, R., Chen, J., Wang, F., Li, Y., Wang, C., Gao, L., Kang, S. (2017): Improved water use efficiency and fruit quality of greenhouse crops under regulated deficit irrigation in northwest China. - Agricultural Water Management 179: 193-204.

[41] Zhang, Q., Bell, L. W., Shen, Y., Whish, J. P. M. (2018): Indices of forage nutritional yield and water use efficiency amongst spring-sown annual forage crops in north-west China. European Journal of Agronomy 93: 1-10.

[42] Zhou, L., Gan, Y., Ou, X., Wang, G. (2011): Progress in molecular and physiological mechanisms of water-saving by compensation for water deficit of crop and how they relate to crop production. - Chinese Journal of Eco-Agriculture 19: 217-225. (in Chinese with English abstract). 